DOI: http://doi.org/10.15688/nav.jvolsu.2017.2.4

UDC 902/904

LBC 63.4(2)

\title{
SARMATIAN BURIAL NEAR THE CITY OF NOVOANNINSKY
}

\author{
Sergey V. Demidenko \\ Institute of Archaeology of RAS, Moscow, Russian Federation \\ Yuriy V. Demidenko \\ State Historical Museum, Moscow, Russian Federation
}

\begin{abstract}
In August 2010, the expedition of the Institute of Archaeology of the Russian Academy of Sciences and the State Research and Production Center for the Protection of Historical and Cultural Monuments of the Volgograd Region conducted rescue excavations of the archaeological heritage site on the territory of the modern cemetery in the city of Novoanninsky, Novoanninsk District, Volgograd Region.

As a result of work, one ancient Sarmatian burial, which was destroyed when constructing modern graves, was investigated.

A wide rectangular grave pit was oriented with a long axis along the line of the NS. Detected at a depth of $0.50-0.55 \mathrm{~m}$ from 0 . Dimensions: $2.95 \times 2.1 \mathrm{~m}$. Diagonally, the burial was cut by a modern grave pit, oriented with a long axis along the NE-SW line. Dimensions: $2.4 \times 0.8 \mathrm{~m}$. The bottom of the ancient burial pit was located at a depth of $1.6 \mathrm{~m}$. Shoulders $0.3-0.4 \mathrm{~m}$ wide were located at a depth of $1.24-1.34 \mathrm{~m}$, along the walls of the ancient burial pit. In situ preserved bones of the legs of an adult, testifying to the fact that he/she laid stretched out on his/her back, head to the south.

The inventory of the burial included a bronze cauldron, a bronze mirror, numerous glass and faience beads, chalk and bronze pendants, a bronze bracelet, a gray-clay bowl, a black-clay vessel, fragments of gray-clay and redclay vessels.

Analysis of the funeral rite and inventory makes it possible to attribute this burial to the Middle Sarmatian culture and to date it within the end of the $1^{\text {st }} \mathrm{c}$. BC - the beginning of the $2^{\text {nd }} \mathrm{c}$. AD.

Key words: the northern part of the Volga-Don interfluve, the Middle Sarmatian culture, burial, bronze mirror, bronze cauldron, beads.
\end{abstract}

Citation. Demidenko S.V., Demidenko Yu.V., 2017. Sarmatian Burial Near the City of Novoanninsky. The Lower Volga Archaeological Bulletin, vol. 16, no. 2, pp. 67-76. (in Russian).

УДК 902/904

ББК 63.4(2)

\section{САРМАТСКОЕ ПОГРЕБЕНИЕ У Г. НОВОАННИНСКИЙ}

Сергей Викторович Демиденко

Институт археологии Российской академии наук, г. Москва, Российская Федерация

Юрий Викторович Демиденко

Государственный исторический музей, г. Москва, Российская Федерация 
Аннотация. В августе 2010 г. экспедиция Института археологии РАН и ГБУК ОНПЦ по охране памятников истории и культуры Волгоградской области провела спасательные раскопки объекта археологического наследия на территории современного кладбища города Новоаннинский Новоаннинского района Волгоградской области.

В результате работ было исследовано одно древнее сарматское погребение, разрушенное при устройстве современной могилы.

Широкая прямоугольная могильная яма была ориентирована длинной осью по линии С-Ю. Обнаружена на глубине 0,50-0,55 м от 0. Размеры: 2,95 × 2,1 м. Погребение было прорезано по диагонали современной могильной ямой, ориентированной длинной осью по линии СВ-ЮЗ. Размеры: $2,4 \times 0,8$ м. Дно древней могильной ямы располагалось на глубине 1,6 м. На глубине 1,24-1,34 м вдоль стенок древней могильной ямы проходили заплечики шириной 0,3-0,4 м. In situ сохранились кости ног взрослого человека, судя по которым, он лежал вытянуто на спине, головой на юг.

В состав инвентаря погребения входили бронзовый котел, бронзовое зеркало, многочисленные стеклянные и фаянсовые бусины, меловые и бронзовые подвески, бронзовый браслет, сероглиняная миска, черноглиняный горшок, фрагменты сероглиняного и красноглиняного сосудов.

Анализ погребального обряда и инвентаря позволяет отнести данное погребение к среднесарматской культуре и датировать в пределах конца I в. до н.э. - начала II в. н.э.

Ключевые слова: северная часть Волго-Донского междуречья, среднесарматская культура, погребение, бронзовое зеркало, бронзовый котел, бусы.

Цитирование. Демиденко С. В., Демиденко Ю. В., 2017. Сарматское погребение у г. Новоаннинский // Нижневолжский археологический вестник. Т. 16, № 2. С. 67-76.

В ноябре 2009 г. в Комитет по культуре Администрации Волгоградской области поступила устная информация из краеведческого музея Новоаннинского района о том, что при рытье экскаватором ямы под могилу на городском кладбище г. Новоаннинский был обнаружен бронзовый древний предмет, судя по описанию, напоминающий сарматский котел.

В начале декабря 2009 г. сотрудники Комитета по культуре выехали на место обнаружения древнего бронзового предмета с целью выяснения обстоятельств находки. В ходе работы комиссии было установлено, что ковш экскаватора нарушил древнее погребение. Признаков курганной насыпи на поверхности данного участка местности членами комиссии зафиксировано не было. На дне современной могильной ямы визуально были отмечены остатки древних человеческих костей, мелкие фрагменты глиняной посуды. Кроме того, в отвале из могилы были собраны: бронзовое зеркало, фрагменты каменной плиты и фрагменты черноглиняного лепного сосуда. Это обстоятельство позволило сделать вывод о том, что современная могильная яма «прорезала» сарматское захоронение I в. н.э. По рекомендации комиссии могильная яма была законсервирована.

В августе 2010 г. экспедиция Института археологии РАН и ГБУК ОНПЦ по охране памятников истории и культуры Волгоградской области провела спасательные раскопки разрушающегося объекта археологического наследия на территории кладбища города Новоаннинский.

\section{Погребение 1}

Широкая подпрямоугольная могильная яма с сильно закругленными углами была ориентирована длинной осью по линии С-Ю. Обнаружена на глубине 0,50-0,55 м от 0. Размеры: 2,95 × 2,1 м. Погребение было прорезано по диагонали современной прямоугольной могильной ямой, ориентированной длинной осью по линии СВ-Ю3. Размеры: $2,4 \times 0,8$ м. Дно современной могильной ямы располагалось на глубине 1,82 м. Дно древней могильной ямы располагалось на глубине 1,6 м. На глубине 1,241,34 м вдоль стенок древней могильной ямы проходили заплечики шириной 0,3-0,4 м. Вся центральная часть древнего погребения оказалась разрушенной современной могильной ямой. In situ coхранились кости ног взрослого человека, судя по которым, он лежал вытянуто на спине, головой на юг. Кости ног сведены в коленях и щиколотках. Кости правой ноги слегка завалены на правую сторону. Под костями прослежен тлен коричневого цвета и пятно мела. В 0,3 м к В от костей ног располагались кости мелкого рогатого скота (рис. 1). 


\section{Инвентарь}

Предметы, обнаруженные in situ:

1. На щиколотках погребенного обнаружены округлые поперечно сжатые и бочковидные укороченные бусы глухого бурого, оранжевого, синего стекла плохой сохранности диаметром $0,3-0,5$ см, диаметр отверстия $-0,1-$ 0,2 см (45 шт.) и стеклянные бусы в виде нерасчлененных столбиков синего цвета, длиной до 0,7 см, диаметром 0,5 см, диаметр отверстия $-0,2$ см (3 шт.) (рис. 4,1).

Предметы, обнаруженные в засыпи современной могильной ямы:

2. Фрагментированная кособокая сероглиняная лощеная миска на кольцевом поддоне. Венчик загнут внутрь. На внешней поверхности видны следы горизонтального лощения, накладывающиеся друг на друга. Диаметр венчика $-17 \times 16$ см, диаметр поддона $-7,5$ см. Ширина кольцевого основания поддона $-1,1 \times 0,7$ см (рис. 3,1).

3. Фрагментированный черноглиняный лепной сосуд. Форма частично реконструируется. Черепок в изломе черный. Имел округлое тулово, плоское дно, короткий отогнутый наружу венчик. Диаметр венчика - 9,5 см, диаметр дна -7 см (рис. 3,2).

4. Фрагментированное дисковидное каменное пряслице. Диаметр $-3 \times 2,8$ см, диаметр отверстия $-0,7$ см (рис. 3,5).

5. Фрагментированное ожерелье (?):

- крупная бусина с внутренней позолотой, диаметр - 1,1 см, диаметр отверстия 0,3 см (рис. 4,2);

- крупная бусина из египетского фаянса, диаметр - 1,3 см, диаметр отверстия - 0,2 см (рис. 4,3);

- бусина из египетского фаянса, диаметр 0,9 см, диаметр отверстия - 0,3 см (рис. 4,4);

- бусина из стекла розовая, диаметр 0,5 см, диаметр отверстия - 0,1 см (рис. 4,5);

- меловая подвеска, размеры 1,6 × 1,4 cм, диаметр отверстия, просверленного под косым углом, $-0,2$ см (рис. 4,6$)$;

- бусина из стекла коричневая, диаметр 0,6 см, диаметр отверстия -0,15 см (рис. 4,7).

- раковина каури (?), размеры $2,5 \times 1,2 \mathrm{~cm}$ (рис. 4,8).

6. Фрагментированная горловина глиняного станкового сосуда. Венчик отогнут на- ружу. В средней части горловины проходит рельефный выступ. Аналогичный выступ отделял горловину от тулова. Тесто хорошо отмученное, в изломе красно-коричневое. Диаметр - 7,5 см (рис. 3,3).

7. Фрагмент стенки сероглиняного сосуда станковой работы. Тесто хорошо отмученное, в изломе серое. Размеры: 5,5 × 3,2 см (рис. 3,4).

Предметы, найденные рабочими при рытье современной могилы в ноябре 2009 г.:

8. Бронзовый литой котел. Тулово полусферической формы, слегка вытянутое по вертикальной оси. Максимальный диаметр расположен в верхней трети тулова. По внешней поверхности проходят рельефные параллельные бороздки. Внутренняя поверхность ровная. Венчик резко отогнут наружу. Имеет две вертикальные кольцевидные ручки с тремя гвоздевидными выступами. Ручки располагаются непосредственно на поверхности венчика котла, диаметрально противоположно друг другу. Между ними на тулове котла, прямо под венчиком, также диаметрально противоположно друг другу располагаются вертикальные овальные ручки-петельки. Под кольцевыми ручками, в месте перехода венчика в тулово, видны округлые следы от использования литейных «пробок». По максимальному диаметру тулова проходит рельефный орнамент в виде «зигзага». Тулово и ручки отлиты одновременно в одной литейной форме. Поддон имел рюмковидную форму, был прилит и укреплен изнутри одной литой «заклепкой».

Тулово котла смято в результате воздействия ковша экскаватора. С одной из сторон на тулове заметно отверстие диаметром $2,5 \times 1,5 \mathrm{~cm}$, которое, возможно, является результатом ритуального «убийства» «души» котла и было пробито в древности. Ниже них прослеживаются три небольших отверстия, являющиеся результатом литейного брака - «недолива». Нижняя часть поддона отломана в древности. Диаметр венчика $-20 \times 16$ см, высота котла - 23 см, высота ручек -3 см, диаметр нижнего основания поддона -5 см, высота поддона -6 см (рис. 2,1).

9. Бронзовое зеркало с небольшой выпуклостью в центре и валиком по краю диска и с боковой ручкой-штырем. Диаметр диска 10,4 см, ширина валика $-1,1$ см, длина ручки $-2,5$ см (рис. 2,2). 
10. Фрагментированная плоская каменная плита неправильной семиугольной формы. Размеры: $23 \times 27,5 \times 1$ см. На внешней стороне сохранились следы от растирания какогото минерального вещества желтого цвета. Размеры: $17 \times 4,5-5$ см.

11. Железный черешок. Длина -4 см (рис. 4,13).

12. Фрагментированное бронзовое изогнутое изделие - браслет (?). Изготовлено из овальной в сечении проволоки. Длина -20 см (рис. 4,10 ).

13. Фрагмент тонкой бронзовой проволоки. Длина -3 см (рис. 4,9).

14. Бронзовое изделие, представляющее собой фигуру в виде двух цилиндриков, согнутых в противоположных направлениях из одного плоского подпрямоугольного листа шириной $1 \mathrm{cm.} \mathrm{В} \mathrm{одном} \mathrm{из} \mathrm{концов} \mathrm{обоих} \mathrm{цилинд-}$ риков пробиты сквозные отверстия для крепления. В центре цилиндриков содержалось органическое вещество, которое не сохранилось (кожа? дерево?) (рис. 4,11).

15. Фрагмент бронзового изделия в виде цилиндрика с органическими остатками внутри. Длина - 1,2 см (рис. 4,12).

16. Кусок смолянистого вещества. На одной стороне сохранились отпечатки ткани. Размеры: $4 \times 2,8$ см (рис. 4,14).

17. Кусок мела. Размеры: $3,5 \times 2,5 \times 1,5 \mathrm{~cm}$ (рис. 4,15).

Несмотря на то что погребение было почти полностью разрушено, полученный материал позволяет определить его место в системе сарматских древностей северной части Волго-Донского междуречья.

Одним из наиболее надежно датирующих предметов из рассматриваемого комплекса является бронзовое зеркало типа 6.7 по классификации А.С. Скрипкина. Основное время бытования зеркал с широким валиком по краю, конусовидной выпуклостью в центре диска и боковой клиновидной ручкой относится к I в. н.э. [Хазанов, 1963, с. 64-65; Скрипкин, 1990, с. 152]. Однако ряд зеркал данного типа обнаружен в комплексах позднего этапа раннесарматской культуры, что позволяет датировать начало проникновения таких зеркал в Волго-Донской регион уже в I в. до н.э. [Минеева, Скрипкин, 2005, с. 52].

Бронзовый литой котел по классификации одного из авторов статьи [Демиденко, 1997, с. 131-132; Демиденко, 2008, с. 22-23] относится к широко распространенному в первые века нашей эры типу XI, который характеризуется полусферическим туловом и рюмковидным поддоном. Однако у описываемого нами экземпляра встречается необычное сочетание форм ручек, на сегодняшний день не отмеченное ни у одного подобного сосуда: кольцевые вертикальные ручки с тремя гвоздевидными выступами сочетаются с ручкамипетельками под венчиком котла. Своеобразен и орнамент на тулове котла: он оформлен в виде «зигзага». Данные факты позволяют рассматривать этот экземпляр в качестве нового варианта типа XI.

Встреченные в исследуемом захоронении фрагменты круговых красноглиняного и сероглиняного сосудов (типы сосудов определить не удалось из-за сильной фрагментированности), изготовленных из глины высокого качества, характерны для керамического комплекса сарматской культуры I-II вв. н.э. [Скрипкин, 1990, с. 161]. Вместе с тем в это же время сохраняются и лепные черноглиняные горшки местного производства с относительно широким горлом и плоским дном, аналогичные найденному в погребении.

Сероглиняные круговые миски широко распространены в меотских памятниках Кубани и Нижнего Дона I-II вв. н.э., откуда они поступают к сарматам Волго-Донского междуречья. Миски на низком кольцевом поддоне с округлым постепенным переходом от стенки к бортику (тип 3п), вероятно, являются наиболее ранними и могут относиться к концу I в. до н.э. [Скрипкин, 1990, с. 160, рис. 45].

Найденные в ногах погребенной в большом количестве мелкие стеклянные одноцветные бусы разных типов, широко известны на протяжении длительного времени, но преобладают в первые века нашей эры [Алексеева, 1978, с. 59]. Бусины с внутренней позолотой и с закраинками вокруг отверстий (тип 1б), аналогичные найденной, отмечены только в погребениях первых веков н.э. [Алексеева, 1975, c. 30]. Широкое распространение египетского фаянса в Северном Причерноморье приходится на период второй половины I в. до н.э.II в. н.э. Округлые гладкие и округлые поперечно сжатые фаянсовые бусины (тип 3г) получают максимум своего распространения в 
I-II вв. н.э. [Алексеева, 1975, с. 31]. Округлая поперечно сжатая розовая бусина с белыми полосками относится к группе бус с продольно-линейным орнаментом, распространенным в период позднего эллинизма и в І в. н.э. [Алексеева, 1978, с. 35]. К первым векам нашей эры относится и максимум распространения подвесок разных типов из меловых пород, а также украшений из раковин морских моллюсков [Алексеева, 1982, с. 27-28].

Интересна находка бронзовых амулетниц в виде одинарного цилиндрика в одном случае и двух спаренных цилиндров, свернутых из одного листа, - в другом. Одна сторона цилиндров в древности была запаяна, с другой прослеживаются отверстия для дужек (утерянных). Внутри цилиндриков - остатки органического вещества. Возможно, эти предметы служили футлярами для хранения тканей, пропитанных ароматическими веществами, и входили в состав ожерелий [Медведев, 1990, с. 90]. Подобные предметы известны в сарматских памятниках Северного Причерноморья - аналогичные амулетницы с остатками органического содержимого, выполненные из золота, происходят из Соколовой Могилы I в. н.э. [Ков- паненко, 1986, с. 95]. Наиболее близкий комплекс с амулетницами в виде двойных цилиндров исследован во II Чертовицком могильнике (кург. 11), расположенном на территории Воронежской области. Здесь, также как и в погребении у Новоаннинского, найдено зеркало с валиком по краю, выступом в центре диска и боковой ручкой-штырем, сероглиняные круговые сосуды, ожерелье из стеклянных бус и бус из египетского фаянса (в том числе пронизь с изображением льва). Верхняя дата совершения этого захоронения определяется найденной здесь фибулой типа «avcissa» - первой половиной I в. н.э. [Медведев, 1990, с. 72].

Положение каменных плит в могилу в ритуальных целях достаточно хорошо известно в погребальном обряде сарматских племен. Совместные находки плит с круговой керамикой позволили датировать данные предметы I - началом II в. н.э. [Скрипкин, 1990, c. 164].

Таким образом, на основании особенностей могильного инвентаря и погребального обряда погребение у г. Новоаннинский можно отнести к концу I в. до н.э. - началу II в. н.э. 


\section{ИЛЛЮСТРАЦИИ}
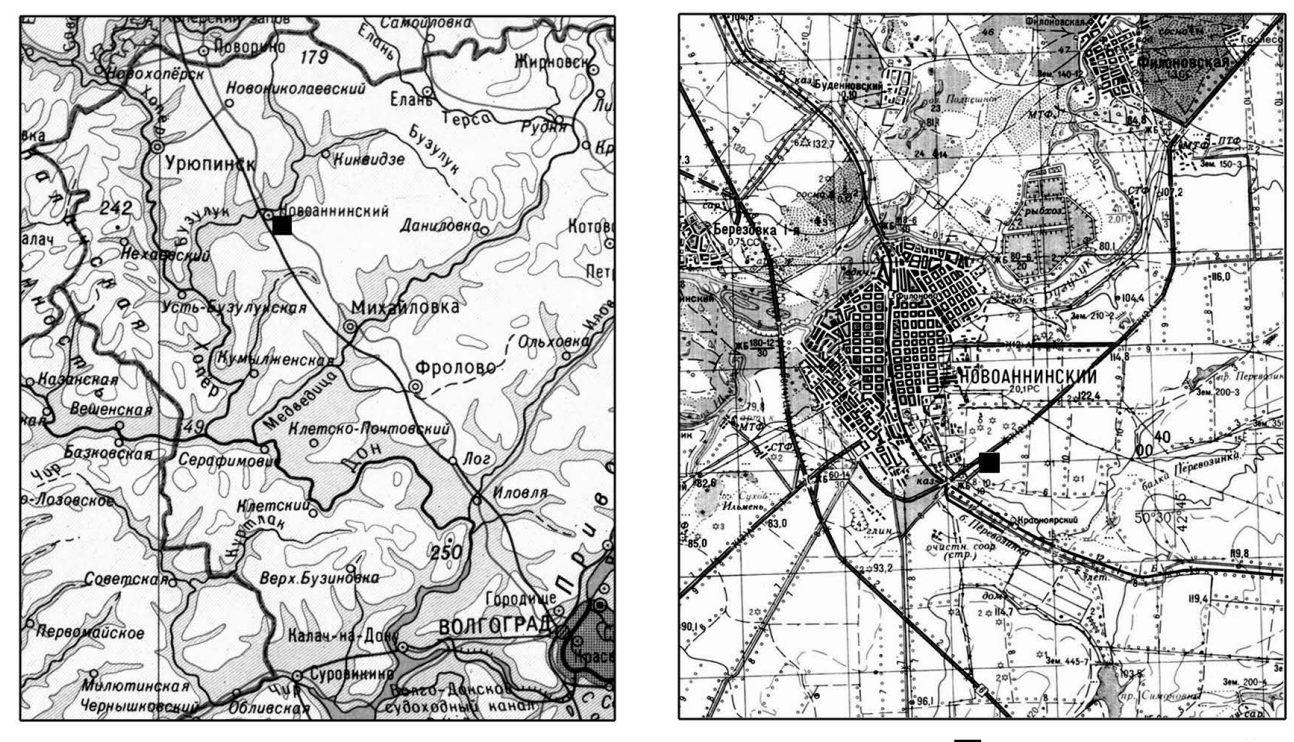

$\square$ - место проведения работ

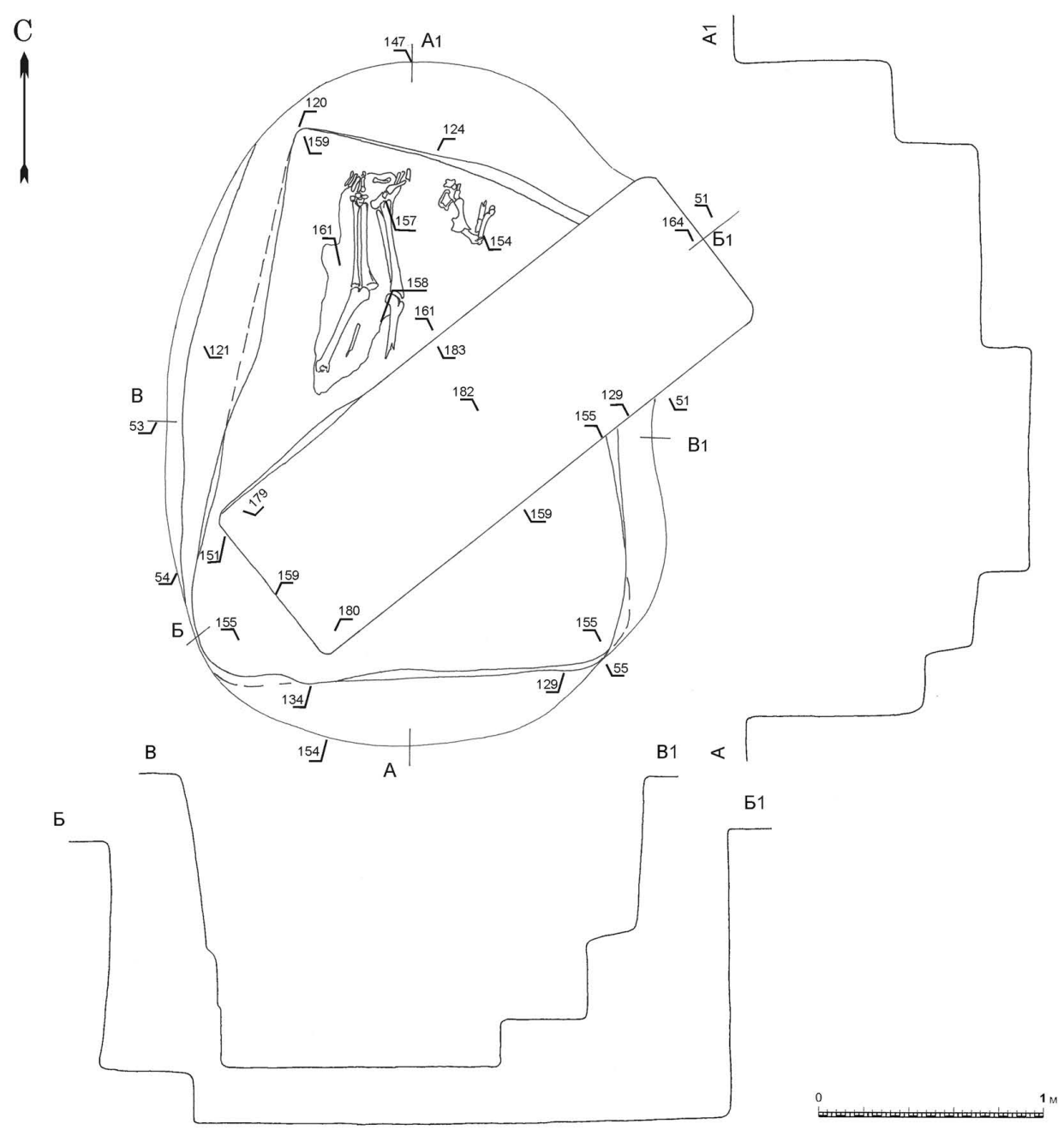

Рис. 1. Сарматское погребение у г. Новоаннинский. План

Fig. 1. Sarmatian burial near the city of Novoanninsky. Plan 

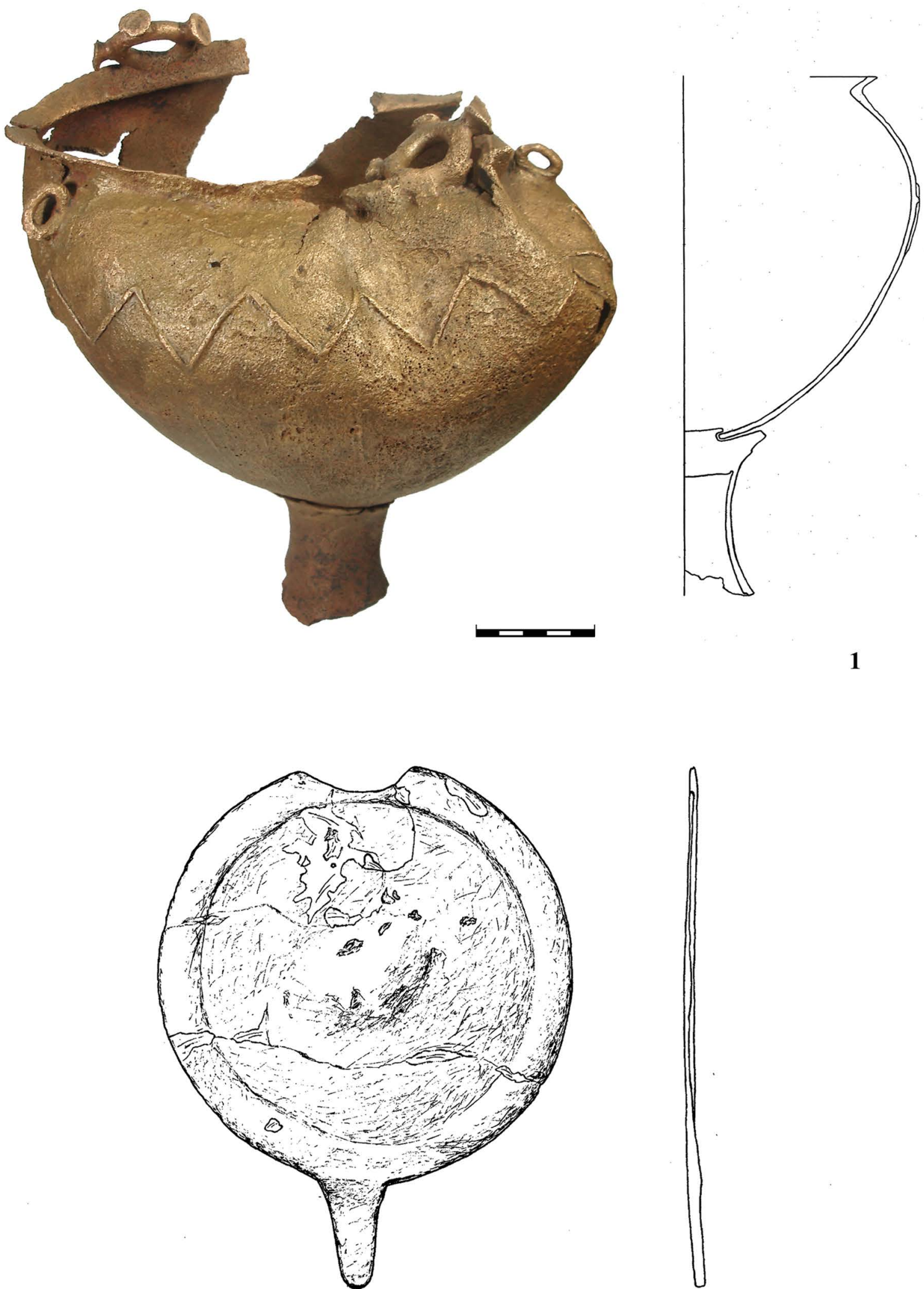

Рис. 2. Сарматское погребение у г. Новоаннинский:

1 - бронзовый котел; 2 - бронзовое зеркало

Fig. 2. Sarmatian burial near the city of Novoanninsky: 1 - bronze cauldron; 2 - bronze mirror 

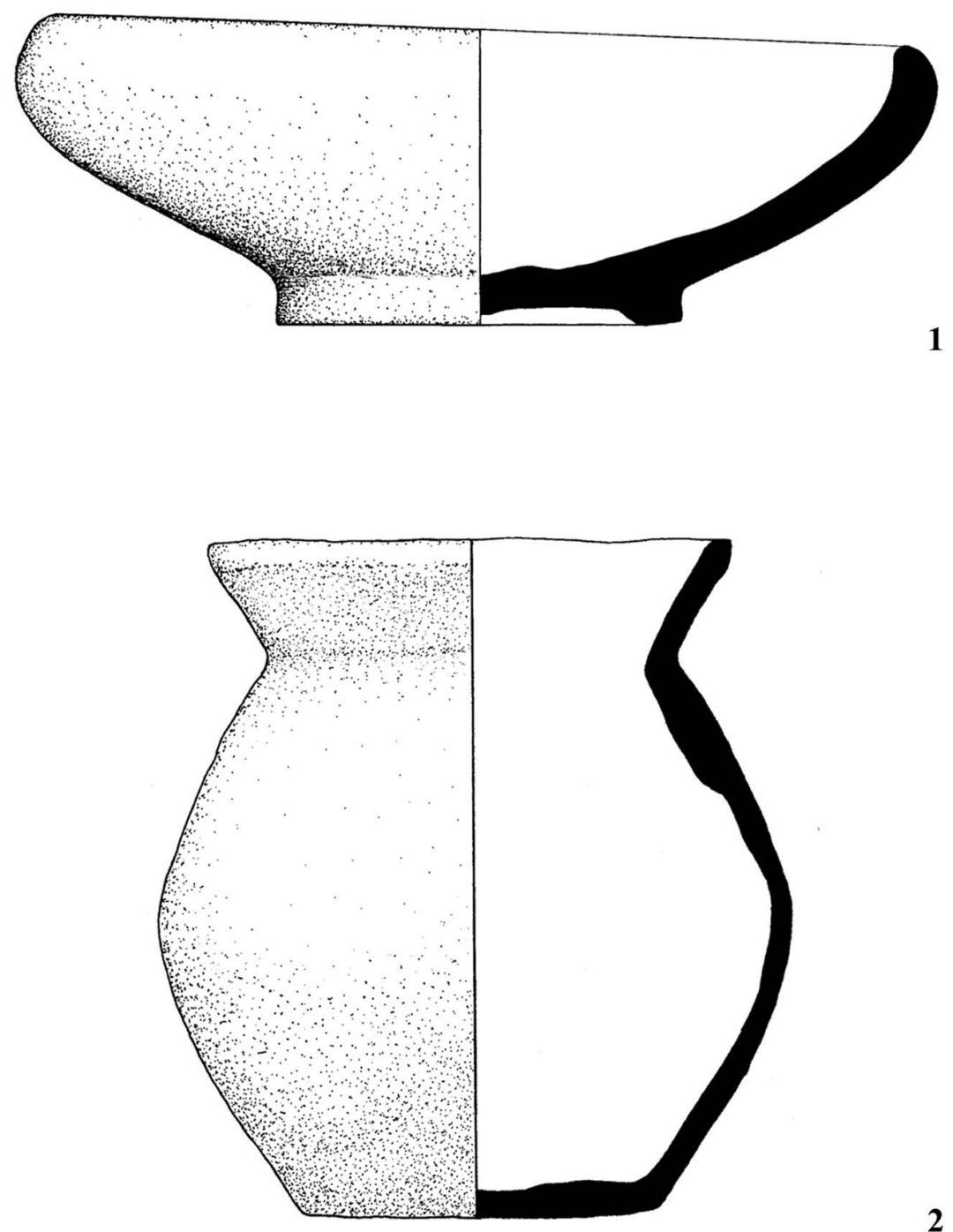

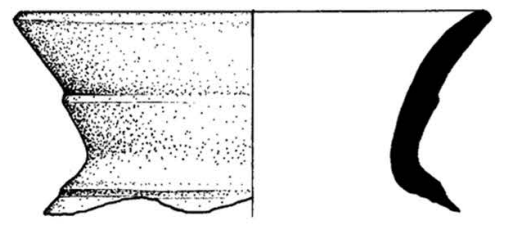

3

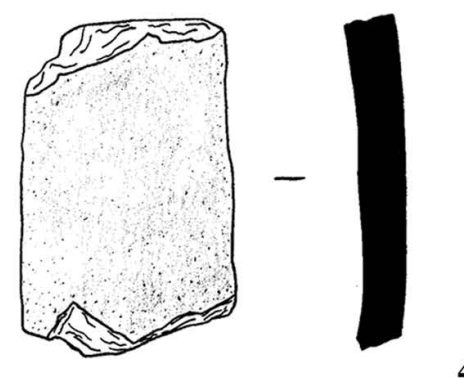

4

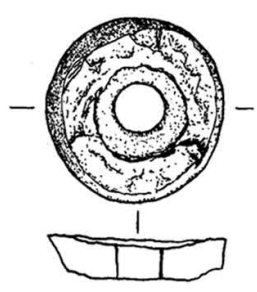

5

Рис. 3. Сарматское погребение у г. Новоаннинский:

1 - сероглиняная миска; 2 - черноглиняный лепной сосуд; 3 - фрагмент красноглиняного сосуда; 4 - фрагмент сероглиняного сосуда; 5 - каменное пряслице

Fig. 3. Sarmatian burial near the city of Novoanninsky:

1 - gray-clay bowl; 2 - black-clay stucco vessel; 3 - fragment of the red-clay vessel;

4 - fragment of the grayclay vessel; 5 - stone spindle 

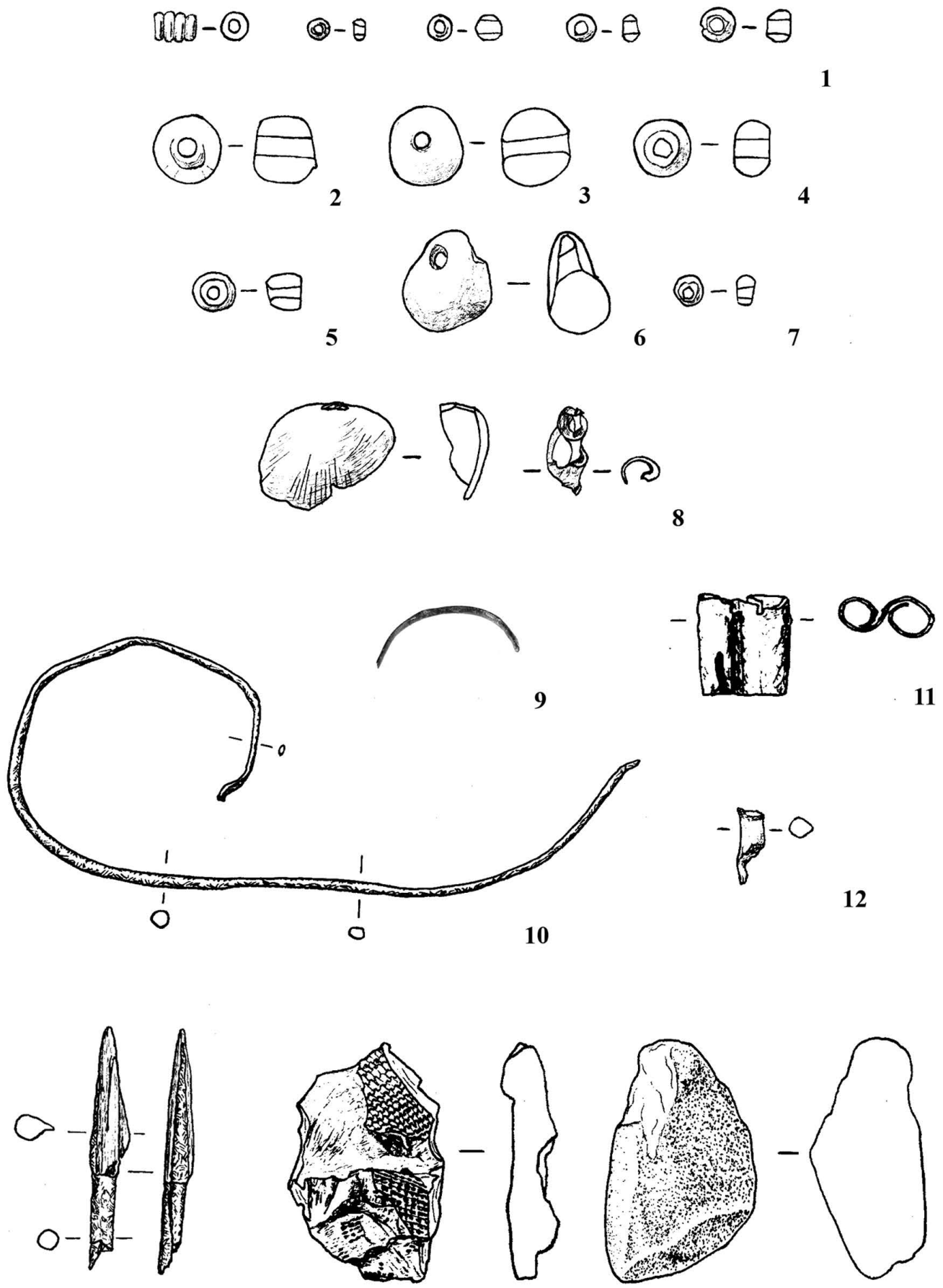

13

14

15

Рис. 4. Сарматское погребение у г. Новоаннинский:

1 - стеклянные бусы; 2 - стеклянная бусина с внутренней позолотой; 3, 4- бусы из египетского фаянса; 5 - розовая стеклянная бусина; 6 - меловая бусина; 7 - коричневая стеклянная бусина; 8 - раковина каури; 9 - фрагмент бронзовой проволоки; 10 - бронзовый браслет; 11,12 - бронзовые подвески; 13 - черешок железный; 14 - кусок мела; 15 - кусок смолянистого вещества

Fig. 4. Sarmatian burial near the city of Novoanninsky:

1 - glass beads; 2 - glass bead with inner gilding; 3, 4- beads from Egyptian faience; 5 - pink glass bead; 6 - chalk bead; 7 - brown glass bead; 8 - cowrey shell; 9 - fragment of bronze wire; 10 - bronze bracelet;

11,12 - bronze pendants; 13 - iron petiole; 14 - piece of chalk; 15 - a piece of resinous substance 


\section{СПИСОК ЛИТЕРАТУРЫ}

Алексеева Е. М., 1975. Античные бусы Северного Причерноморья. М. : Наука. 118 с.

Алексеева Е. М., 1978. Античные бусы Северного Причерноморья. М. : Наука. 120 с.

Алексеева Е. М., 1982. Античные бусы Северного Причерноморья. М. : Наука. 105 с.

Демиденко С. В., 1997. Типология котлов савроматосарматского времени с территории Нижнего Поволжья, Подонья и Северного Кавказа // Древности Евразии. М. : ГИМ: МГУ. С. 120-159.

Демиденко С. В., 2008. Бронзовые котлы древних племен Нижнего Поволжья и Южного Приуралья (V в. до н.э. - III в. н.э.). М. : Изд-во ЛКИ. 328 с.

Ковпаненко Г. Т., 1986. Сарматское погребение I в. н.э. на Южном Буге. Киев : Наукова думка. 152 с.

Медведев А. П., 1990. Сарматы и лесостепь. Воронеж : Изд-во Воронеж. ун-та. 220 с.

Минеева О. И., Скрипкин А. С., 2005. О происхождении и времени появления одного из типов бронзовых зеркал у сарматов // Нижневолжский археологический вестник. Вып. 7. С. 51-56.

Скрипкин А. С., 1990. Азиатская Сарматия. Проблемы хронологии и ее исторический аспект. Саратов : Изд-во Сарат. ун-та. 300 c.

Хазанов А. М., 1963. Генезис сарматских бронзовых зеркал // СА. № 4. С. 58-71.

\section{REFERENCES}

Alekseyeva E.M., 1975. Ancient beads of the North Pontic Region. Moscow, Nauka Publ. 118 p. (in Russian).
Alekseyeva E.M., 1978. Ancient beads of the North Pontic Region. Moscow, Nauka Publ. 120 p. (in Russian).

Alekseyeva E.M., 1982. Ancient beads of the North Pontic Region. Moscow, Nauka Publ. 105 p. (in Russian).

Demidenko S.V., 1997. Typology of cauldrons of the Savromat-Sarmatian time from the territory of the Lower Volga region, the Don region and the North Caucasus. Antiquities of Eurasia. Moscow, GIM, MGU, pp. 120-159. (in Russian).

Demidenko S.V., 2008. Bronze cauldrons of ancient tribes of the Lower Volga and Southern Urals (V century $B C$ - III century $A D$ ). Moscow, Izdvo LKI. 328 p. (in Russian).

Kovpanenko G.T., 1986. Sarmatian burial from the first century BC on the Southern Bug. Kiev, Naukova Dumka Publ. 152 p. (in Russian).

Medvedev A.P., 1990. Sarmatians and foreststeppe. Voronezh, Izd-vo VGU. 220 p. (in Russian).

Mineeva O.I., Skripkin A.S., 2005. About an origin and time of occurrence of one of the types of bronze Sarmatian mirrors. The Lower Volga archaeological bulletin, iss. 7, pp. 51-56. (in Russian).

Skripkin A.S., 1990. Asian Sarmatia. Problems of chronology and its historical aspect. Saratov, Izd-vo Sarat. un-ta. 300 p. (in Russian).

Hazanov A.M., 1963. The Genesis of the Sarmatian bronze mirrors. Sovetskaia arkheologiia, no. 4, pp. 58-71. (in Russian).

\section{Information about the Authors}

Sergey V. Demidenko, Candidate of Sciences (History), Researcher, Department of ScythianSarmatian Archaeology, Institute of Archaeology of RAS, Dmitriya Ulyanova St., 19, 117036 Moscow, Russian Federation, svdemidenko@hotmail.com.

Yuriy V. Demidenko, Researcher, Department of Archaeology, State Historical Museum, Red Square, 1, 109012 Moscow, Russian Federation, yvdemidenko@mail.ru.

\section{Информация об авторах}

Сергей Викторович Демиденко, кандидат исторических наук, научный сотрудник Отдела скифо-сарматской археологии, Институт археологии РАН, ул. Дмитрия Ульянова, 19, 117036 г. Москва, Российская Федерация, svdemidenko@hotmail.com.

Юрий Викторович Демиденко, научный сотрудник отдела археологических памятников, Государственный исторический музей, Красная площадь, 1, 109012 г. Москва, Российская Федерация, yvdemidenko@mail.ru. 